\title{
Preparation of $<001>$ Oriented PZT Thin Films and the Applications to Micro Piezoelectric Devices
}

\author{
Ryoichi Takayama Non-member (Matsushita Electric Industrial Co., Ltd.) \\ Eiji Fujii Non-member (Matsushita Electric Industrial Co., Ltd.) \\ Takeshi Kamada Non-member (Matsushita Electric Industrial Co., Ltd.) \\ Akiko Murata Non-member (Matsushita Electric Industrial Co., Ltd.) \\ Taku Hirasawa Member (Matsushita Electric Industrial Co., Ltd.) \\ Atsushi Tomozawa Non-member (Matsushita Electric Industrial Co., Ltd.) \\ Satoru Fujii Non-member (Matsushita Electric Industrial Co., Ltd.) \\ Hideo Torii Non-member (Matsushita Electric Industrial Co., Ltd.) \\ Koji Nomura Non-member (Matsushita Electric Industrial Co., Ltd.)
}

Keywords : PZT, piezoelectric thin film, ferroelectrics, sputtering deposition, angular rate sensor, piezoelectric actuator, inkjet printer head

$\mathrm{Pb}(\mathrm{ZrTi}) \mathrm{O}_{3}(\mathrm{PZT})$ are attractive materials for sensors and actuators in MEMS because of their excellent piezoelectric properties. We found that the $<001>$ oriented PZT thin films deposited on $\mathrm{MgO}$ substrate by rf-magnetron sputtering, had excellent piezoelectric properties without a poling treatment.

In this study, we investigated the preparation of $<001>$ oriented PZT thin films on $\mathrm{Si}$ substrate, and their applications to the angular rate sensors and the actuators of the inkjet printer head.

PZT thin films, which have a composition near the morphotropic phase boundary, were deposited on (100)Pt/(100)MgO and (111)Pt/Ti/(100)Si substrates by rf-magnetron sputtering. The substrate temperature is $500-650^{\circ} \mathrm{C}$. A sintered ceramic target with a composition of $\left[0.8\left(\mathrm{PbZr}_{0.53} \mathrm{Ti}_{0.47} \mathrm{O}_{3}\right)+0.2(\mathrm{PbO})\right]$ was used. (111) Pt thin films are deposited by rf-magnetron sputtering on (100)Si substrates with $\mathrm{Ti}$ adhesion layer. Film thickness of the PZT films were 2.0-4.0 $\mu \mathrm{m}$.

The $<001>$ oriented PZT thin films were obtained on $(100) \mathrm{Si}$ substrates by means of the optimizing the sputtering conditions of $\mathrm{PZT}$ and (111)Pt/Ti thin films. Figure 1 shows the XRD pattern of the PZT thin films deposited on (111)Pt/Ti/(100)Si substrates.

The piezoelectric properties of the PZT thin films were examined on the micro fabricated cantilever structure. Table 1 shows the dielectric and piezoelectric properties of the

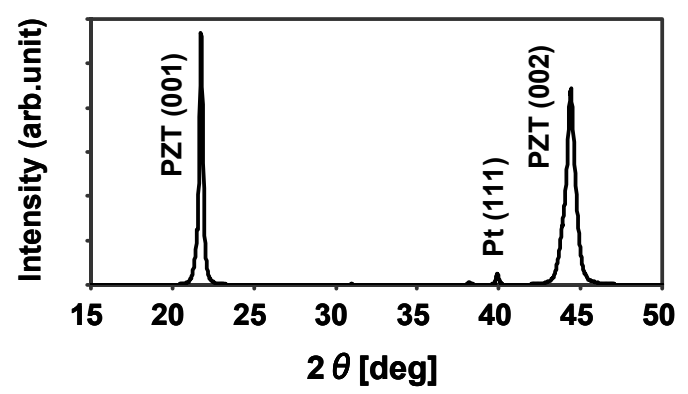

Fig. 1. XRD pattern of the PZT thin films deposited on (111)Pt/Ti/Si
$<001>$ oriented PZT thin films. The PZT thin films on $\mathrm{Pt} / \mathrm{MgO}$ have high piezoelectric coefficient $d_{31}=100 \times 10^{-12} \mathrm{~m} / \mathrm{V}$, extremely low $\varepsilon_{\mathrm{r}}=240$, and remarkably high electromechanical coupling coefficient $k_{31}$. The PZT thin films on Pt/Ti/Si have very high $d_{31}$ of $150 \times 10^{-12} \mathrm{~m} / \mathrm{V}$ and $\varepsilon_{\mathrm{r}}=700$. Both of these thin films show excellent piezoelectric properties without a poling treatment.

The PZT thin films were applied to the angular rate sensors with a tuning fork type and the actuators of the ink-jet printer heads with 400 pressure chambers.

Figure 2 show the photographs of the angular rate sensors. These sensors have high sensitivity of $25 \mathrm{mV} /\left(\mathrm{deg} \mathrm{s}^{-1}\right)$.

These PZT thin films are suitable for the use in micro piezoelectric sensors and actuators.

Table 1. Dielectric and piezoelectric properties of the $<001>$ oriented PZT thin films

\begin{tabular}{c|c|c|c}
\hline & $\begin{array}{c}\text { Piezoelectric } \\
\text { coefficient } \\
d_{31}\left[10^{-12} \mathrm{~m} / \mathrm{V}\right]\end{array}$ & $\begin{array}{c}\text { Relative } \\
\text { dielectric } \\
\text { constant: } \varepsilon_{\mathrm{r}}\end{array}$ & $\begin{array}{l}\text { Electromechanical } \\
\text { coupling } \\
\text { coefficient }: k_{31}\end{array}$ \\
\hline$<001>\mathrm{PZT} / \mathrm{Pt} / \mathrm{MgO}$ & 100 & 240 & 0.62 \\
\hline$<001>\mathrm{PZT} / \mathrm{Pt} / \mathrm{Si}$ & 150 & 700 & 0.55 \\
\hline
\end{tabular}

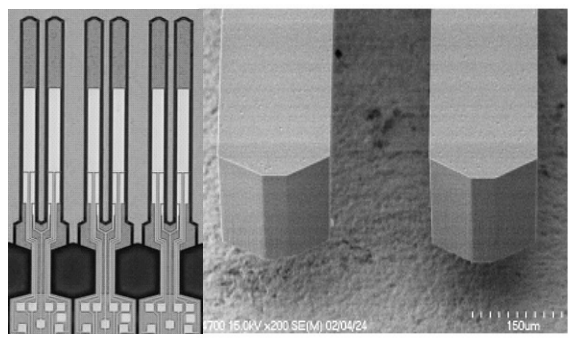

(a)

(b)

Fig. 2. The tuning fork type angular rate sensors. (a) The angular rate sensors after the Si tuning fork forming process. (b) The top of the Si tuning fork 


\section{$<001>$ 配向 PZT 薄膜の作製とマイクロ圧電素子への応用}

\begin{tabular}{|c|c|c|c|c|c|}
\hline 非会員 & 高山 & 良一* & 非会員 & 藤井 & 映志* \\
\hline 非会員 & 鎌田 & 健* & 非会員 & 村田 & 晶子* \\
\hline 正 員 & 平澤 & 拓* & 非会員 & 友澤 & 淳* \\
\hline 非会員 & 藤井 & 覚* & 非会員 & 鳥井 & 秀雄* \\
\hline 非会員 & 野村 & 幸治* & & & \\
\hline
\end{tabular}

\section{Preparation of $<001>$ Oriented PZT Thin Films and the Applications to Micro Piezoelectric Devices} Ryoichi Takayama*, Non-member, Eiji Fujii*, Non-member, Takeshi Kamada*, Non-member, Akiko Murata*, Non-member, Taku Hirasawa*, Member, Atsushi Tomozawa*, Non-member, Satoru Fujii*, Non-member, Hideo Torii*, Non-member, Koji Nomura*, Non-member

Preparation of $<001>$ oriented $\mathrm{Pb}(\mathrm{ZrTi}) \mathrm{O}_{3}(\mathrm{PZT})$ thin films and their applications to the micro-piezoelectric devices were investigated. The $<001>$ oriented PZT thin films, which have a composition near the morphotropic phase boundary, were deposited on $\mathrm{Pt} / \mathrm{MgO}$ and $\mathrm{Pt} / \mathrm{Ti} / \mathrm{Si}$ substrates by rf-magnetron sputtering. Both of these thin films show the excellent piezoelectric properties without a poling treatment. The piezoelectric properties of the PZT thin films were examined on the micro fabricated cantilever structure. The PZT thin films on Pt/MgO have high piezoelectric coefficient $d_{31}=100 \times 10^{-12} \mathrm{~m} / \mathrm{V}$, extremely low $\varepsilon_{\mathrm{r}}$ $=240$, and remarkably high electromechanical coupling coefficient $k_{31}$. The PZT thin films on Pt/Ti/Si have very high $d_{31}$ of $150 \times$ $10^{-12} \mathrm{~m} / \mathrm{V}$ and $\varepsilon_{\mathrm{r}}=700$. The PZT thin films on Pt/Ti/Si were applied to the angular rate sensors with a tuning fork type and the actuators of the ink-jet printer heads with 400 pressure chambers. These PZT thin films are suitable for the use in micro piezoelectric sensors and actuators.

キーワード : PZT 圧電薄膜, 強誘電体, スパッタリング法, 角速度センサ, 圧電アクチュエータ, インクジェットプリンタヘッド

Keywords : PZT piezoelectric thin films, ferroelectrics, sputtering deposition, angular rate sensor, piezoelectric actuator, inkjet printer head

\section{1. まえがき}

強誘電体は，高い誘電率，優れた圧電性・焦電性・強誘 電性や電気光学特性をもつ興味深い材料であり，多岐にわ たる電子デバイスに応用されている。これらの強誘電体を 利用したデバイスも，高周波化・高効率化・低電圧化・小 型化・集積化等の要求が高まっており, 強誘電体の薄膜化 が強く要望されている。

電気信号と機械信号とを相互に変換する圧電性を有する

\footnotetext{
* 松下電器産業 $($ 株)

$<$ 代表 $>$

先行デバイス開発センター

T570-8501 大阪府守口市八雲中町 3-1-1

Advanced Devices Development Center, Matsushita Electric

Industrial Co., Ltd.

3-1-1 Yagumo-naka-machi, Moriguchi City, Osaka 570-8501

先端技術研究所 ナノテクノロジー研究所

厂 619-0237 京都府相楽郡精華町光台 3-4

Nonotechnology Research Laboratory Advanced Technology

Research Laboratories, Matsushita Electric Industrial Co., Ltd.

3-4 Hikaridai, Seika-cho, Soraku-gun, Kyoto 619-0237
}

材料は, MEMS プロセス技術の発展により, マイクロセン サやマイクロアクチュエータのキー材料のひとつとして注 目されている。なかでも, チタン酸ジルコン酸鉛 $\left(\mathrm{PbZrTiO}_{3}\right.$ : PZT）は, ペロブスカイト構造の強誘電体で, モルフォトロ ピック相転移境界近傍では, 圧電特性が著しく高められる ので, その薄膜化の研究開発が盛んに行われている(1) (3)。

われわれは RF マグネトロンスパッタリング法を用いて 幅広い応用が期待できるペロブスカイト型構造の強誘電体 薄膜に関する研究開発を行ってきた ${ }^{(4) \sim(6)}$ 。分極軸となる $<001>$ 方向に配向させて, 高い焦電特性や圧電特性を示すチ タン酸鉛系薄膜, $\mathrm{PZT}$ 薄膜を $\mathrm{MgO}$ 単結晶基板上に作製する ことができた ${ }^{(4) \sim(10)}$ 。同時に, 従来の強誘電体材料にはみら れない，作製時から分極方向が揃う現象を見出した。さら に, MEMS 技術と融合したマイクロ圧電素子への忘用を目 指し, $\mathrm{Si}$ 基板上に高い圧電特性を示寸薄膜材料の作製を試 みた。その結果, RF マグネトロンスパッタリング法により Si 基板上に $<001>$ 配向 PZT 薄膜を作製することができるよ 
うになった。また， $\mathrm{Si}$ 基板上に作製した PZT 薄膜において も，分極処理をしなくとも高い圧電特性が得られた。

本稿では，本薄膜の作製と特性，ならびに，本薄膜を用 いた角速度センサやインクジェットプリンタ（IJP）ヘッド 用アクチュエータの作製とそれらの特性について述べる。

\section{2. < <01 配向 PZT 薄膜の作製}

PZT 薄膜は，RF マグネトロンスパッタリング法により作 製した。ターゲットには，モルフォトロピック相境界近傍 の組成に $20 \mathrm{~mol} \%$ 過剰の $\mathrm{PbO}$ を混合した焼結体 $\left[0.8\left(\mathrm{PbZr}_{0.53} \mathrm{Ti}_{0.47} \mathrm{O}_{3}\right)+0.2 \mathrm{PbO}\right.$ を用いた。基板は, $\mathrm{Si}(100)$ に $\mathrm{Ti}$ 密着層と $\mathrm{Pt}$ を形成したものと, 比較のため, (100)でへき開 した $\mathrm{MgO}$ 単結晶に(100)Pt を形成したものの 2 種類である。 Pt はスパッタリング法で形成し, その膜厚は 50〜 100nm で ある。スパッタリング条件としては，基板温度を 500〜 $650^{\circ} \mathrm{C}$, 成膜速度を $10 \sim 50 \mathrm{~nm} / \mathrm{min}$. と変化して, 膜厚が $2 \sim 4$ $\mu \mathrm{m}$ の PZTを作製した。

\section{3. < <01>配向 PZT 薄膜の特性}

〈3·1〉 結晶性·配向性 作製した PZT 薄膜の結晶構 造・配向性は X 線回折で評価, 薄膜のマイクロ構造は SEM で観察した。また，薄膜の組成は，ICP 質量分析と X 線マ イクロアナライザーにより評価した。PZT 薄膜の $\mathrm{Zr} / \mathrm{Ti}$ 比は, ターゲット組成とほぼ一致した。

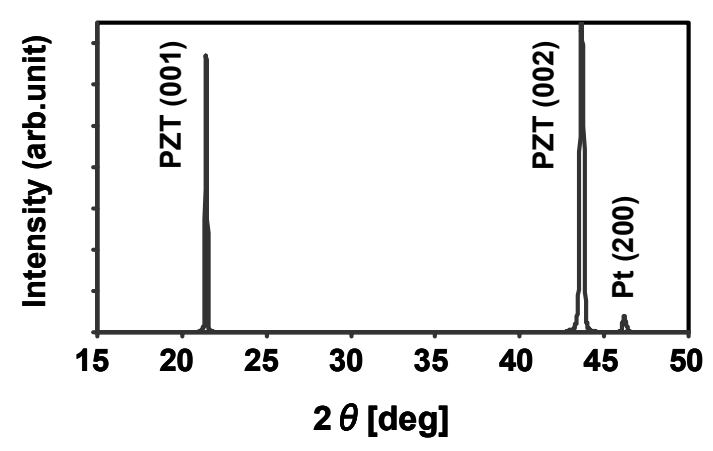

Fig. 1. XRD pattern of the PZT thin films deposited on (100) $\mathrm{Pt} /(100) \mathrm{MgO}$ single crystal substrate.

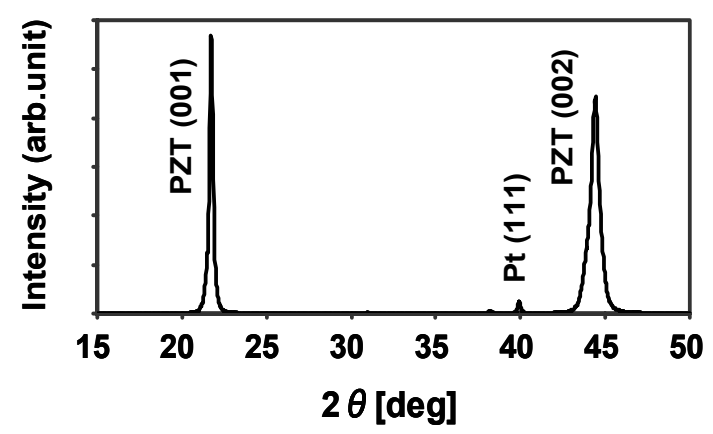

Fig. 2. XRD pattern of the PZT thin films deposited on (111)Pt/Ti/Si substrate.
ペロブスカイト構造の薄膜は, 基板温度 $550 \sim 650^{\circ} \mathrm{C}$ で安 定して得られた。これらの基板温度の範囲では, 基板温度 とともに $\mathrm{Pb} /(\mathrm{Zr}+\mathrm{Ti})$ 比が低下し, 基板温度 $650^{\circ} \mathrm{C}$ で化学量論 的組成 1 に近づいた。

(100) $\mathrm{Pt} / \mathrm{MgO}$ 単結晶基板上には, ペロブスカイト構造の $\mathrm{PZT}$ 薄膜が $540^{\circ} \mathrm{C}$ 以上でエピタキシャル成長した。図 1 に, 基板温度 $600^{\circ} \mathrm{C}$ で(100)Pt $/ \mathrm{MgO}$ 基板上に作製した PZT 薄膜の $\mathrm{X}$ 線回折パターンを示す。格子定数が $0.414 \mathrm{~nm}$ で, 正方晶 の $\mathrm{c}$ 軸 $<001>$ に配向している。

$\mathrm{Si}$ 基板上には, 下地電極やスパッタ条件の最適化で $<001>$ 配向の PZT 薄膜が得られた。図 2 は, (111)Pt/Ti/(100)Si 基板 上に作製した PZT 薄膜の X 線回折パターンである。(001) 面の強いピークが観測され，<001>に配向している。

図 3 に, (111)Pt/Ti/Si 上に作製した PZT 薄膜断面の SEM 像を示す。緻密な柱状構造の膜が形成できている。

〈3-2〉圧電測定方法 3 種類の構造を持つ試料 A,B,C を作製し圧電特性を測定した。試料 A と B は, カンチレバ 一構造の試料である。試料 $\mathrm{A}$ は, 基板上に $\mathrm{Pt}$ 電極, $\mathrm{PZT}$ 薄 膜, 上部電極を形成し, Pt 電極は $\mathrm{Ar}$ イオンエッチングで, $\mathrm{PZT}$ は $\mathrm{HF}$ と $\mathrm{HNO}_{3}$ によるウエットエッチングでパターン化 した。その後, 基板をエッチングで除去した。基板側と上 部の電極の膜厚は $100 \mathrm{~nm}$ と同じ膜厚にし, カンチレバーの 幅は $50 \mu \mathrm{m}$, 長さは 100～500 $\mu \mathrm{m}$ である (図 4 参照)。

試料 $\mathrm{B}$ は A の上部 $\mathrm{Pt}$ 電極上に, 非圧電層として感光性の ポリイミド膜を $2 \mu \mathrm{m}$ 形成した構造である ${ }^{(9)}$ 。試料 $\mathrm{C}$ は, 基 板をエッチングしないでそのままにして, 基板の幅を $3 \mathrm{~mm}$, 長さ $14 \mathrm{~mm}$ の短冊に加工して, これを片端で固定した。

試料 A の試料では, 電圧を印加して横方向の伸び縮みを レーザ顕微鏡で測定した。そして, 次式より圧電定数 $d_{31}$ を 求めた。

$$
\begin{aligned}
& d_{31}=\frac{d l}{l} \frac{t}{V} \\
& \text { ここで, } t: \mathrm{PZT} \text { の膜厚, } V: \text { 印加電圧, } \\
& l, d l \text { : カンチレバーの長さ, 伸び }
\end{aligned}
$$

また, 試料 $\mathrm{B}, \mathrm{C}$ では, 正弦波電圧を印加して, その撓み 振動の変位量 $\delta$ をレーザードップラー振動計で測定した。 そして, 次式より圧電定数 $d_{31}$ を求めた。

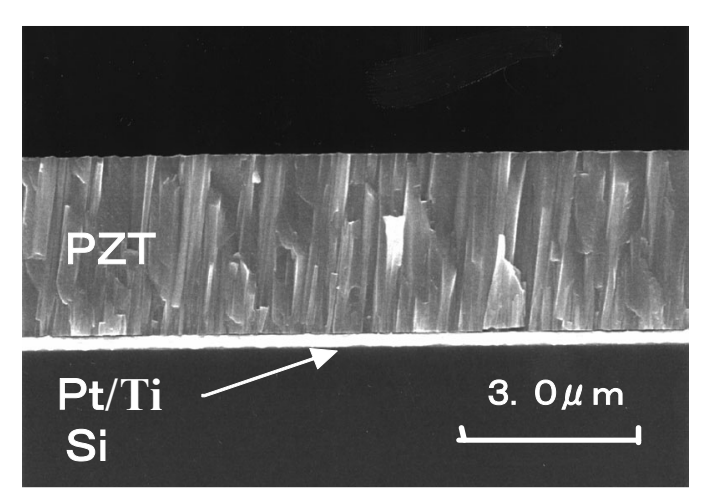

Fig. 3. SEM images of the cross section of the $<001>$ oriented PZT thin films. 

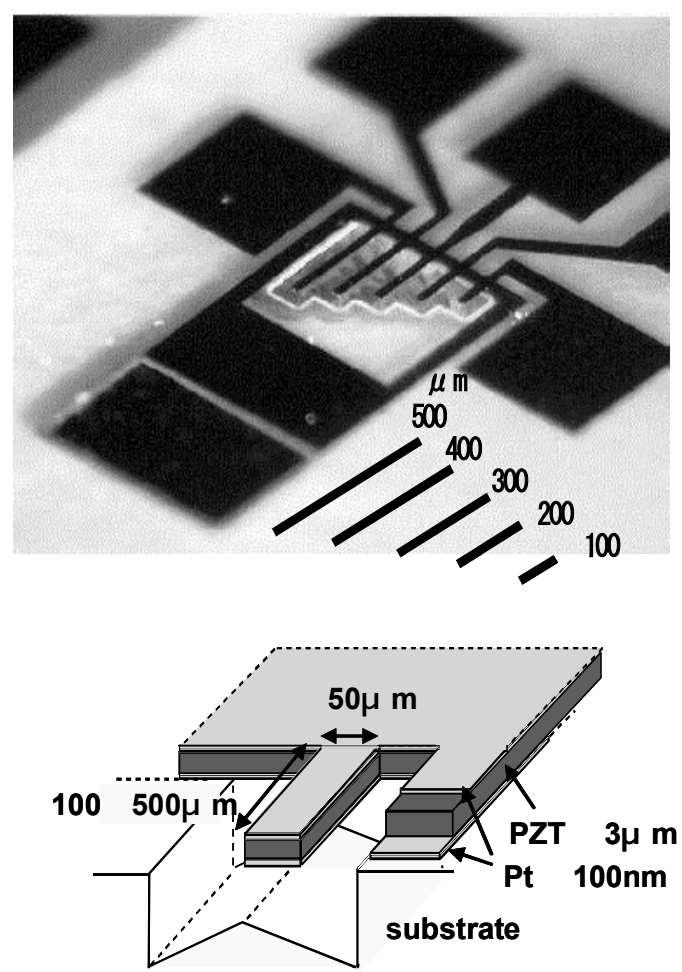

Fig. 4. The sample A with the cantilevers for piezoelectric measurement.

$\delta=\frac{3 d_{31} s_{1} s_{2} t_{1}\left(t_{1}+t_{2}\right) l^{2} V}{s_{1}{ }^{2} t_{2}^{4}+4 s_{1} s_{2} t_{1} t_{2}^{3}+6 s_{1} s_{2} t_{1}^{2} t_{2}^{2}+4 s_{1} s_{2} t_{1}^{3} t_{2}+s_{2}{ }^{2} t_{1}^{4}}$

ここで, $t_{1}, t_{2}: \mathrm{PZT}, \mathrm{Si}$ またはポリイミドの膜厚,

$s_{1}, s_{2}: \mathrm{PZT}, \mathrm{Si}$ またはポリイミド膜の弾性コンプ

ライアンス。

〈3.3〉 圧電特性 $\mathrm{MgO}$ 基板上に作製した $<001>$ 配向 PZT 薄膜で 3 種類の構造を有する試料 A，B，C を評価した 結果，同じスパッタリング作製条件で作製した PZT 薄膜で は，試料 $\mathrm{A} ， \mathrm{~B} ， \mathrm{C}$ とも $d_{31}$ の值は， $-100 \times 10^{-12} \mathrm{~m} / \mathrm{V}$ と，ほ ぼ同じ值が得られた。ただし，すべての試料は，分極処理 を行っていない。また, PZT 薄膜の弾性コンプライアンス の值を, カンチレバーのアドミッタンスの共振周波数から $s_{1}=10.8 \times 10^{-12} \mathrm{~m}^{2} / \mathrm{N}$ とした。

$\mathrm{Si}$ 基板上に作製した PZT 薄膜では，試料 C で撓夕振動の 変位量を測定し，圧電特性を評価した。圧電定数 $d_{31}$ の值は $-150 \times 10^{-12} \mathrm{~m} / \mathrm{V}$ が得られた。ただし，Si 基板上 PZT の試 料も，す心゙て分極処理を行っていない。

図 5 に, $\mathrm{Si}$ 基板上に作製した PZT 薄膜の圧電定数 $d_{31}$, 比 誘電率 $\varepsilon_{\mathrm{r}}$ とスパッタ作製時の基板温度との関係を示した。 基板温度が $570^{\circ} \mathrm{C}$ 以上で高い圧電定数が得られ, それ以上の 温度では, 温度とともに圧電定数は低下している。ペロブ スカイト構造の PZT が作製できる基板温度では，基板温度 とともに $\mathrm{Pb} /(\mathrm{Zr}+\mathrm{Ti})$ 比が低下していることから, 少し $\mathrm{Pb} リ$ ッチな組成で圧電定数 $d_{31}$ がピークを示した。

図 6 に, カンチレバー構造で測定した変位特性を示す。 電圧に対して良好なリニアリティを示している。

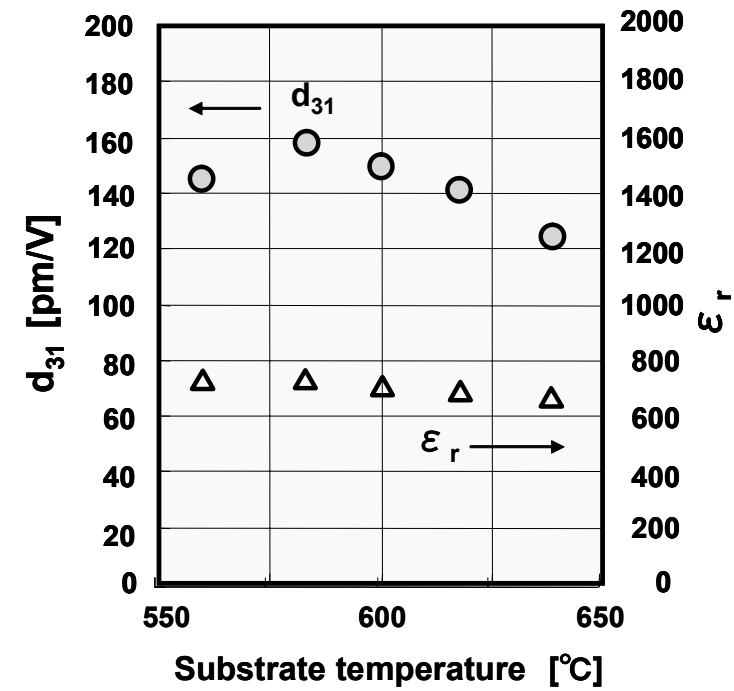

Fig. 5. Relationship between $d_{31}$, $\varepsilon_{\mathrm{r}}$ of $<001>$ oriented PZT and the substrate temperature.

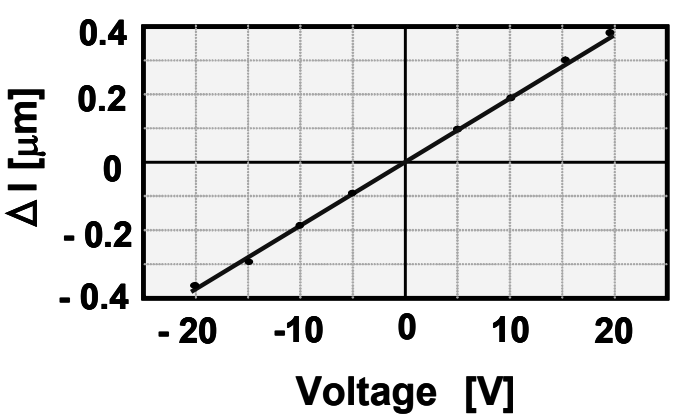

Fig. 6. Displacement property of the $<001>$ oriented PZT thin films.

比誘電率 $\varepsilon_{\mathrm{r}}$ の測定值 (LCR メーター, at $1 \mathrm{kHz}$ ) は, $\mathrm{MgO}$ 基板上 PZT 薄膜が 240 と小さく, $\mathrm{Si}$ 基板上の PZT 薄膜は, 700 の值が得られた。これらの $\varepsilon_{\mathrm{r}}$ の值は, PZT 薄膜の $<001>$ 配向性と内部応力に強く依存していると考えられる。 $\mathrm{MgO}$ 基板上の PZT 薄膜には, スパッタ中の成長過程で生じる圧 縮応力となる真性応力に, PZT より基板の方が大きな熱膨 張係数であるために生じる圧縮応力となる熱応力が加わ り, 膜中には大きな圧縮応力が存在する。つまり, 非常に 大きな圧縮応力により膜面方向では拘束された状態になっ ている。また, $\mathrm{Si}$ 基板上の PZT 薄膜は, 圧縮応力である真 性応力と引張り応力となる熱応力で, 最終的に引張り応力 が残存していると思われる。なお, $\mathrm{PbZr}_{0.53} \mathrm{Ti}_{0.47} \mathrm{O}_{3}$ の組成で は, 応力: $T$ が一定のとき, 誘電率 $\varepsilon_{33}{ }^{\mathrm{T}}=580, \quad \varepsilon_{11}{ }^{\mathrm{T}}=1080$, また, $x$ 軸方向に伸縮を許さないように拘束したときの誘電 率 $\varepsilon_{33} \mathrm{~S}=300$ の值が示されている(11)。

電気機械結合係数 $k_{31}=d_{31} /\left(\varepsilon_{33}{ }^{\mathrm{T}} \mathrm{s}_{11}{ }^{\mathrm{E}}\right)^{1 / 2}$ を計算した。 $\mathrm{PZT} / \mathrm{MgO}$ で 0.62, $\mathrm{PZT} / \mathrm{Si}$ で 0.55 と大きな值が得られた。

$\mathrm{MgO}$ 基板と $\mathrm{Si}$ 基板に作製した $<001>$ 配向 PZT 薄膜の誘 電・圧電特性をまとめて表 1 に示す。 
Table 1. Properties of the $<001>$ oriented PZT thin films.

\begin{tabular}{c|c|c|l}
\hline & $\begin{array}{c}\text { Piezoelectric } \\
\text { coefficient }: d_{31} \\
{\left[10^{-12} \mathrm{~m} / \mathrm{V}\right]}\end{array}$ & $\begin{array}{c}\text { Dielectric } \\
\text { constant: } \\
\varepsilon_{\mathrm{r}}\end{array}$ & $\begin{array}{l}\text { Coupling } \\
\text { coefficient }: k_{31}\end{array}$ \\
\hline$<001>\mathrm{PZT} / \mathrm{Pt} / \mathrm{MgO}$ & 100 & 240 & 0.62 \\
\hline$<001>\mathrm{PZT} / \mathrm{Pt} / \mathrm{Si}$ & 150 & 700 & 0.55 \\
\hline
\end{tabular}

Coupling coefficient : $k_{31}=d_{31} /\left(\varepsilon_{33}{ }^{\mathrm{T}} \mathrm{s}_{11}{ }^{\mathrm{E}}\right)^{1 / 2}$

\section{PZT 薄膜を用いた圧電素子}

〈4·1〉 角速度センサ <001>配向 PZT 薄膜を用いた 角速度センサ（音叉型振動ジャイロ）の構造模式図を図 7 に示す。(100)Si 基板上に $\mathrm{Pt} / \mathrm{Ti}$ (下地電極)，<001>配向 PZT 薄膜, 上部電極を成膜後, 膜のパターンニングを行い, そ れぞれの電極膜と PZT をエッチング除去する。最後に Si を ドライエッチングで音叉の形状に仕上げた。

電極には，音叉のアームを図の $\mathrm{x}$ 軸方向に速度 V で瓦い に逆相で振動させる駆動電極と, $\mathrm{y}$ 軸の周りに角速度が入力 されると $\mathrm{z}$ 軸方向に発生するコリオリカによる音叉アーム の撓みで発生する電気信号を検出する電極とが, PZT 薄膜 上に同一平面状に同時に形成されている。

ドライエッチングにより $\mathrm{Si}$ 音叉に加工した音叉型振動ジ ヤイロ素子群の写真を図 8(a)に示す。また, $\mathrm{Si}$ の音叉アーム の先端部を図 8(b)に示す。この音叉アームは, 厚さ $200 \mu \mathrm{m}$ にわたってほぼ垂直になるように加工し，音叉不要信号を 極めて小さくすることができた。

高い $d_{31}, k_{31}$ と，良好なリニアリティを示す変位特性とを 有する $<001>$ 配向 PZT 薄膜と, Si のドライエッチングによ る高精度に形成した音叉により, カーナビゲーションに要 求される $25 \mathrm{mV} /\left(\mathrm{deg} \cdot \mathrm{s}^{-1}\right)$ の感度を実現した。

表 2 に，角速度センサの諸特性を示す。

〈4·2〉 インクジェットプリンタヘッド用アクチュエー タ PZT 薄膜と振動膜からなるアクチュエータ部, 圧力 室，インク共通液室，ノズルから構成され，400ノズル，400 圧力室をもつアクチュエータアレイを作製した。

図 9 に, <001>配向 PZT 薄膜を用いたインクジェットプリ ンタヘッドの 1 ノズル・1 圧力室に対応した断面模式図を示 す。また, 図 10 に, 400 ノズルのアクチュエータアレイを 上部（Pt 薄膜側）から見た写真を示す。100ノズルが 4 列に 配置され，白く光っているところが各 Pt 電極である。

基板上に，下地電極膜，<001>配向 PZT 薄膜，金属振動膜 を成膜後, 膜のパターンニングを行い, 下地電極膜, PZT 膜をエッチング除去し，各圧力室上に配置できるように形 成する。アクチュエータ部の変位と共振周波数を測定後,

インク室・流路をもつエレメントと撥水膜をコーティング したノズルを形成したエレメントをボンディングして作製 した ${ }^{(12)}$ 。

インクは, 共通液室から供給孔を通じて個別の圧力室・ ノズルまで充填される。圧力室上部に形成されたアクチュ

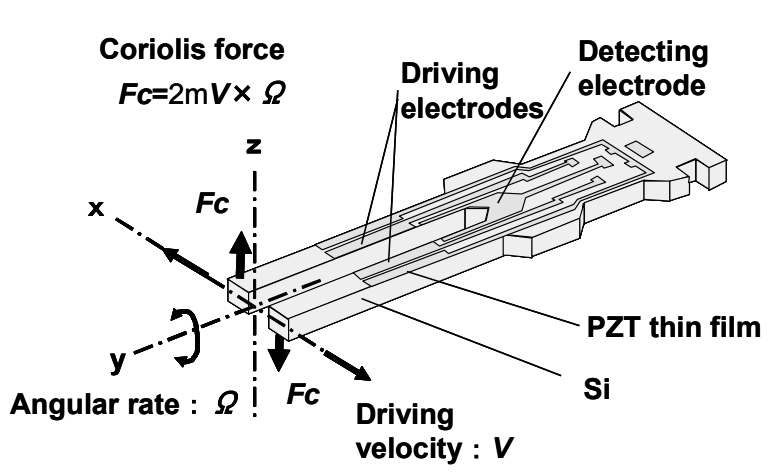

Fig. 7. Structure of the angular rate sensors.

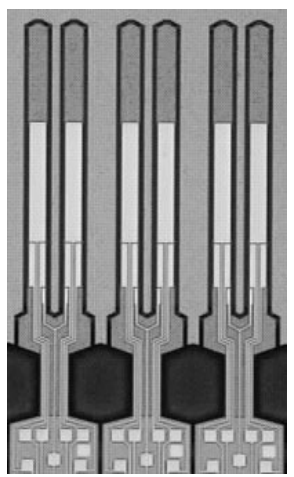

(a) The angular rate sensors after the Si tuning fork forming process

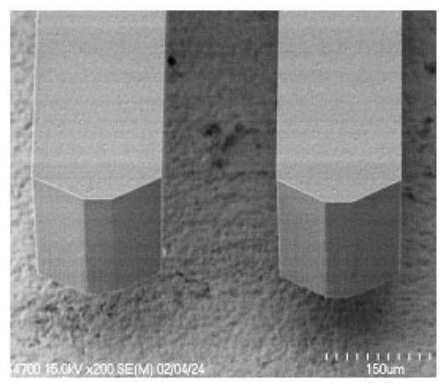

(b) The top of the Si tuning fork

Fig. 8. The tuning fork type angular rate sensors.

Table 2. Characteritics of the tuning fork type angular rate sensors.

\begin{tabular}{l|c}
\hline Sensitivity & $25 \mathrm{mV} /\left(\mathrm{deg} \cdot \mathrm{s}^{-1}\right)$ \\
\hline Output Noise & $<10 \mathrm{mV}_{\mathrm{p}-\mathrm{p}}$ \\
\hline Output Voltage Range & $0.3 \sim 4.7 \mathrm{~V}$ \\
\hline Operating Temp. Range & $-40 \sim 85{ }^{\circ} \mathrm{C}$ \\
\hline
\end{tabular}

エータ部のたわみ振動により, 圧力室内のインクに圧力を 加え，ノズルよりインクが吐出される。

$3 \mu \mathrm{m}$ の PZT 薄膜によるアクチュエータ部により, 小型 化・高速化・低電圧化が可能となり, 微少量吐出・マルチ パス多值吐出制御・安定吐出・高寿命化（>10 10 drops）が 実現された。 


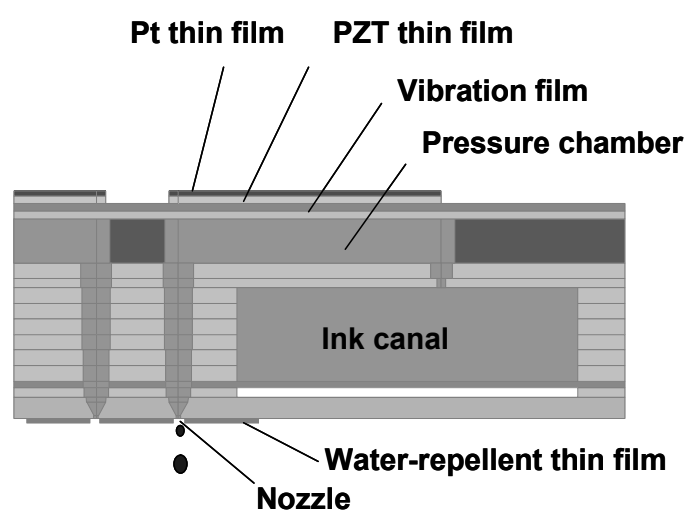

Fig. 9. The structure of the actuator for inkjet printer head.

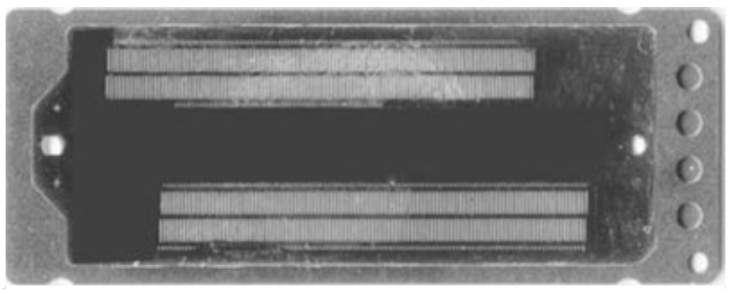

Fig. 10. The line head with 400 nozzles and 400 pressure chambers.

\section{5. あとがき}

$\mathrm{RF}$ マグネトロンスパッタリング法による PZT 薄膜の作製 と, その音叉型角速度センサ・インクジェットプリンタ用 アクチュエータへの応用に関する研究開発を行った。

下地電極 $\mathrm{Pt} / \mathrm{Ti}$ や PZT スパッタリング条件の最適化で, Si 基板上に緻密な膜構造をもつ $<001>$ 配向 PZT 薄膜を作製す ることができた。圧電評価の結果，本 PZT 薄膜は，分極処 理をしなくとも, PZT セラミックより大きな圧電定数 $d_{31}$ $(=150)$ が得られ, 比誘電率 $\varepsilon_{\mathrm{r}}(=700)$, 高い電気機械結合係 数 $k_{31}$ を示し, 変位特性も良好なリニアリティを有した。

本 PZT 薄膜化技術を利用して, 小型の音叉型角速度セン サやインクジェットプリンタヘッド用アクチュエータアレ イを作製した。これらの圧電応用素子において，マイクロ 化の 1 つの方向を示すことができた。

また, 本 PZT 薄膜の HDD 用 2 段アクチュエータへの試み もあり, サスペンションの共振モードを励起せず高い周波 数まで追従可能, $\pm 5 \mathrm{~V}$ と低電圧駆動などの特長が示されて いる(13)(14)。

なお，分極方向が揃う現象については，オージェ電子分 光法の分析結果により, 薄膜の厚み方向の組成が均一であ ったので, 内部応力とひずみによるものと考えられる。し かし, $\mathrm{MgO}$ 基板上の圧縮応力, $\mathrm{Si}$ 基板上の引張り応力にか かわらず，PZT 薄膜の分極方向が揃うので，今後，この機 構を解明したい。同時に，本技術により，他用途のマイク 口圧電素子への展開を期待したい。

\section{謝 辞}

本研究開発は多くの方々の御指導と御援助により進展し たものであり, 京都大学工学部の神野伊策助教授, パナソ ニックエレクトロニックデバイス (株)・パナソニックコミ ユニケーションズ社の開発担当者の皆様に感謝の意を表し ます。

(平成 19 年 4 月 26 日受付, 平成 19 年 7 月 18 日再受付)

\section{文献}

(1) T. Maeder, P. Muralt, L. Sagalowicz, I. Reaney, M. Kohli, and N. Setter : " $\mathrm{Pb}(\mathrm{ZrTi}) \mathrm{O}_{3}$ thin films on zirconium membranes for micromechanical applications", Appl. Phys. Lett., Vol.68, pp.776-778 (1996)

(2) S. Watanabe, T. Fujiu, and T. Fujii : "Effect of poling on piezoelectric properties of lead zilconate titanate thin films formed by sputtering", Appl. Phys. Lett., Vol.66, pp.1481-1483 (1995)

(3) C. Lee, T. Itoh, and T. Suga : "Micromachined ppiezoelectric force sensors based on PZT thin films", IEEE Trans. Ultrason. Ferroelectr. Freq. Cont., Vol.43, pp.553-559 (1996)

(4) K. Iijima, Y. Tomita, R. Takayama, and I. Ueda : "Preparation of c-axis oriented $\mathrm{PbTiO}_{3}$ thin films and their crystallographic, dielectric, and pyroelectric properties", J. Appl. Phys., Vol.60, pp.361-367(1986)

( 5 ) K. Iijima, R. Takayama, Y. Tomita, and I. Ueda : "Epitaxial growth and the crystallographic, dielectric, and pyroelectric properties of lanthanummodified lead titanate thin films", J. Appl. Phys., Vol.60, pp.2914-2919 (1986)

(6) R. Takayama and Y. Tomita : "Preparation of epitaxial $\mathrm{Pb}\left(\mathrm{Zr}_{\mathrm{x}} \mathrm{Ti}_{1-\mathrm{x}}\right) \mathrm{O}_{3}$ thin films and their crystallographic, pyroelectric, and ferro-electric properties”, J. Appl. Phys., Vol.65, pp.1666-1670 (1989)

(7) 高山良一：「強誘電体薄膜を用いた焦電型赤外線センサー」, 応用物 理, Vol.64, No.12, pp.1221-1224 (1995)

(8) I. Kanno, S. Fujii, T. Kamada, and R. Takayama : "Piezoelectric properties of c-axis oriented $\mathrm{Pb}(\mathrm{Zr}, \mathrm{Ti}) \mathrm{O}_{3}$ thin films", Appl. Phys. Lett., Vol.70, No.11, pp.1378-1380 (1997)

(9) I. Kanno, S. Fujii, T. Kamada, and R. Takayama : "Piezoelectric characteristics of c-axis oriented $\mathrm{Pb}(\mathrm{Zr}, \mathrm{Ti}) \mathrm{O}_{3}$ thin films", J. Korean Physical Society, Vol.32, pp.S1481-1484 (1998)

(10) S. Fujii, I. Kanno, T. Kamada, and R. Takayama : "Preparation of c-axis oriented $\mathrm{Pb}(\mathrm{Zr}, \mathrm{Ti}) \mathrm{O}_{3}$ thin films by RF-magnetron sputtering and their dielectric and piezoelectric properties", Jpn. J. Appl. Phys., Vol.36, pp.6065-6058 (1997)

(11) 電子材料工業会 :「圧電セラミックスとその応用」, 電波新聞社, pp.92-95 (1974)

(12) K. Tomita, H. Horio, K. Chikanawa, O. Watanabe, Y. Toyofuku, K. Matsuo, and M. Ooyama : "Preparation of c-axis oriented $\mathrm{Pb}(\mathrm{Zr}, \mathrm{Ti}) \mathrm{O}_{3}$ thin films by RF-magnetron sputtering and their dielectric and piezoelectric properties", Matsuhita. Technical Journal, Vol.51, pp.75-79 (2005)

(13) H. Kuwajima and K. Matsuoka : "Thin-film piezoelectric DSA for HDD", IEEE Trans. Magn., Vol.38, pp.2186-2188 (2002)

(14) H. Uchiyama, Y. Ogawa, H. Kita, and H. Kuwajima : "Thin film piezoelectric dual-stage actuator for HDD" Technical Report of IEICE, Vol.MR2002-82, pp.17-22 (2003) (in Japanese)

内山博一・小川裕子・喜多弘行・桑島秀樹 :「薄膜 PZT を用いた HDD 用新型二段アクチュエータの開発」, 信学会技報, MR2002-82, pp.17-22 (2003)

高 山 良 -

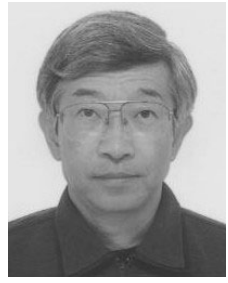

（非会員）1973 年 4 月松下電器産業 (株) 入社, 同年 11 月中央研究所, 1976 年材料研究所, 1994 年中央研究所薄膜グループ勤務。現在, 先行デ バイス開発センターに所属。微粒子化技術·薄 膜化技術による機能性材料とその応用素子, 特 に, 強誘電体材料の薄膜化とセンサ・アクチュ エータ素子への応用に関する研究開発に従事。 工学博士。 


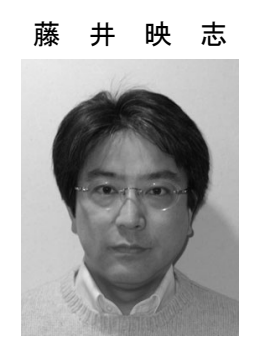

（非会員） 1984 年 4 月松下電器産業（株）入社, 同年無線研究所, 1994 年中央研究所, 2001 年 カラープリンティング開発センター, 2003 年先 行デバイス開発センター, 現在, 先端技術研究 所，ナノテクノロジー研究所勤務。ナノプロセ ス技術グループのグループマネージャー。機能 性材料の薄膜化技術・ナノプロセス技術とその 応用に関寸る研究開発に従事。工学博士。

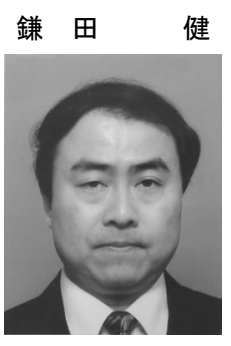

（非会員） 1986 年 4 月松下電器産業（株）に入 社。同年中央研究所, 1995 年生活環境研究所, 2001 年カラープリンティング開発センター勤 務。半導体・超伝導・強誘電体の薄膜化技術に 関する研究開発に従事。現在，先行デバイス開 発センター勤務，機能性薄膜材料およびその応 用デバイスに関する研究開発に従事。

\section{村田晶子}

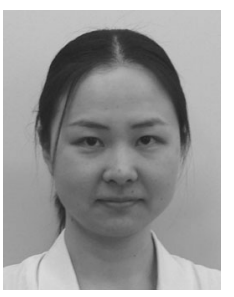

（非会員） 1999 年 4 月松下電器産業 (株) 入社。 同年くらし環境開発センター, 2001 年カラープ リンティング開発センター勤務, 光触媒材料 . PZT 圧電材料等の酸化物薄膜化技術に従事。現 在, 先行デバイス開発センター勤務, ナノコン ポジット材料に関する研究開発に従事。

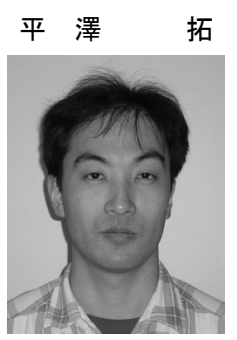

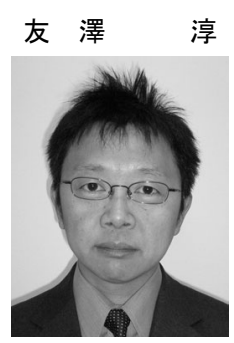

享（非会員） 1990 年 4 月松下電器産業（株）に入 社。同年電子部品研究所, 1991 年部品デバイス 研究センター, 1994 年中央研究所, 2003 年先 行デバイス開発センター勤務。強誘電体・半導 体 - 磁性体酸化物の薄膜化技術の研究開発に従 事。現在, 松下電器半導体社プロセス開発セン ターに勤務, イメージセンサのプロセス開発に 従事。

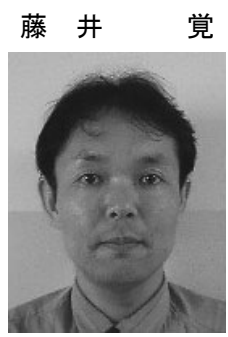

（非会員） 1989 年 4 月松下電器産業（株）入 社, 同年部品デバイス研究開発センター, 1994 年中央研究所, 1995 年生活環境研究所, 2001 年カラープリンティング開発センター勤務。強 誘電体薄膜を用いた赤外線センサ, 圧電デバイ スの研究開発に従事。現在, 先行デバイス開発 センター勤務, 薄膜メモリ材料の研究開発に従 事。

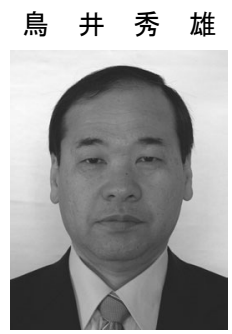

(非会員) 1980 年 4 月松下電器産業 (株) 入社。 同年無線研究所, 1991 年部品デバイス開発セン ター, 1993 年中央研究所, 2001 年カラープリ ンティング開発センター, 2003 年先行デバイス 開発センター勤務。酸化物磁性体・半導体・誘 電体の薄膜化研究に従事。現在, 映像デバイス 開発センター勤務, 薄膜・厚膜材料プロセスの 研究開発に従事。理学博士。

野 村 幸 治

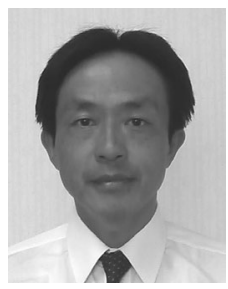

（非会員） 1981 年 4 月松下電器産業 (株) 入社, 同年中央研究所，1991 年松下電子部品（株）開 発技術センター勤務。現在, パナソニックエレ クトロニックデバイス（株）開発技術センター 勤務。センサ・アクチュエータ, $\mathrm{RF}$ ・光機能素 子の薄膜\&MEMS 関連デバイスの研究開発に 従事。工学博士。 